\title{
Alternative Oral Agents in Prophylaxis and Therapy of Uterine Fibroids-An Up-to-Date Review
}

\author{
Michał Ciebiera ${ }^{1, *}$ (D) , Krzysztof Łukaszuk ${ }^{2,3}$, Błażej Męczekalski ${ }^{4}$, Magdalena Ciebiera ${ }^{5}$, \\ Cezary Wojtyła ${ }^{1}$, Aneta Słabuszewska-Jóźwiak ${ }^{1}$ and Grzegorz Jakiel ${ }^{1}$ \\ 1 Department of Obstetrics and Gynecology, The Centre of Postgraduate Medical Education, \\ 00-416 Warsaw, Poland; czwo@op.pl (C.W.); as.jozwiak@op.pl (A.S.-J.); grzegorz.jakiel1@o2.pl (G.J.) \\ 2 Department of Obstetrics and Gynecological Nursing, Faculty of Health Sciences, \\ Medical University of Gdansk, 80-210 Gdansk, Poland; luka@gumed.edu.pl \\ 3 INVICTA Fertility and Reproductive Center, 80-172 Gdansk, Poland \\ 4 Department of Gynecological Endocrinology, Poznan University of Medical Sciences, 60-513 Poznan, Poland; \\ blazejmeczekalski@yahoo.com \\ 5 Students' Scientific Association at the I Department of Obstetrics and Gynecology, \\ Medical University of Warsaw, 02-015 Warsaw, Poland; mciebiera93@gmail.com \\ * Correspondence: michal.ciebiera@gmail.com; Tel.: +48-607-155-177
}

Received: 17 October 2017; Accepted: 28 November 2017; Published: 1 December 2017

\begin{abstract}
Uterine fibroids (UFs) are the most common tumors of the female genital tract. The effect of UFs on the quality of life and the overall cost of treatment are significant issues worldwide. Tumor size and location are the two specific factors which influence the occurrence of symptoms, the need for, and method of, treatment (some tumors require surgery while some can be treated with selected drugs). Primary prevention and treatment of early UF disease are worthy goals that might have a great impact on health care systems. Several treatments and prophylactic methods can be used in this endeavor. This publication presents current data about lesser-known substances which may have a beneficial effect on the treatment or prophylaxis of UFs and can be administered orally, serving as an alternative to (or complement of) surgery or selective progesterone receptor modulators (SPRMs). Early prevention and treatment of UFs in women from high-risk groups should be our priority. Innovative forms of UF management are under intensive investigation and may be promising options in the near future. Many of them evaluated vitamin D, paricalcitol, epigallocatechin gallate (EGCG), elagolix, aromatase inhibitors (AIs), and cabergoline and deemed them to be safe and effective. The next step in such projects should be properly constructed randomized control trials (RCTs), carried out by successive phases.
\end{abstract}

Keywords: uterine fibroid; leiomyoma; vitamin D; paricalcitol; epigallocatechin gallate; elagolix; aromatase inhibitors; cabergoline; pharmacology

\section{Introduction}

Uterine fibroids (UFs) - benign monoclonal tumors protruding from myometrial smooth muscle cells-are the most common pathology of the female genital tract [1-3]. The morphology of UFs may vary greatly. They can be solitary or appear in multiple clusters. Also, their size range is considerable, too, from miniscule to giant masses of over $20 \mathrm{~cm}$ in diameter. UFs affect $25-80 \%$ women, depending on the population and the risk factors $[2,4,5]$. The majority of UFs are asymptomatic, and menopause generally results in tumor atrophy, but the symptomatic tumors constitute a major problem for the vast number of affected women. The wide range of UF-associated symptoms includes iron deficiency anemia, abdominal and pelvic pain, gastrointestinal disorders, dysuria, female infertility, and severe obstetric complications $[2,4,6]$. 
This pathology varies greatly in relation to age. These tumors are more prevalent among older populations $[2,7,8]$. UFs are not observed in pre-pubescent girls and are a rare finding in adolescents, indicating that they depend on hormonal changes $[7,9]$. According to the available data, the growth of UFs depends mostly on the influence of steroid hormones [1,10,11]. Estrogens have been known to play an important role in the pathophysiology of UFs, but the latest research has suggested progesterone as the main factor initiating pathological uterine muscle differentiation and abnormal growth [1]. The main mechanism of progesterone-induced UFs tumorigenesis consists of an increase in the concentration of selected growth factors [1,12,13]. Also, a significant part of UFs occurs due to a genetic abnormality [1]. In patients with positive family history, the risk for developing UFs approximately 4 times higher than in the general population [14]. According to a study by Makinen et al., specific mutations within the gene encoding the mediator complex subunit 12 (MED12) were detected in the examined UFs [15]. Nowadays, it is a known fact that even up to $80 \%$ of UFs have a mutation in MED12 [1,15,16].

UFs are a major public health problem. By the age of 50, they might develop in almost $80 \%$ and $70 \%$ of the African-American and the Caucasian women, respectively $[3,8]$. The effects of UFs on the quality of life (QoL) and the overall cost of treatment are significant but often remain unaddressed or marginalized [17]. As far as QoL for women in general is concerned, Soliman et al. have recently demonstrated that women who rated their UF-related symptoms as "severe" had significantly worse QoL as compared to their peers with mild symptoms [18]. QoL deteriorated considerably with the increasing number and severity of symptoms [18]. A 2015 review of the literature on direct and indirect costs of UF management revealed that substantial sums of money are generated by UFs [19], and included not only the price of medicines, medical staff salaries, or the cost of surgical treatment, but also the hidden costs of work absence, hospitalization, control visits, and preoperative diagnostic tests. The annual direct and indirect costs of UFs in the United States have been estimated to be between $\$ 4.1-\$ 9.4$ billion $[3,19,20]$, and $\$ 1.6-\$ 17.2$ billion, respectively [20]. In the United States, the total cost of treatment of a single patient with UFs ranges from $\$ 11,700$ to $\$ 25,000$ per year after the diagnosis or surgery $[19,21]$. According to a well-known study by Cardozo et al., the total annual cost of UF treatment in the United States has been estimated at $\$ 34.4$ billion [20].

Tumor size and location determine the occurrence of symptoms, the need for treatment, and the treatment method. Other important determinants include symptom severity, patient age and reproductive plans, the risk for malignancy, skills and expertise of the gynecologists and access to proper medical equipment $[2,6]$. Due to the benign nature of UFs, treatment resulting in the least morbidity and lowest risk should be chosen, if possible [2,6,22]. Multiple UF management options are currently available but surgery remains the method of choice and is often accompanied by pharmacological treatment or pretreatment [2,22-24]. The most common complaint-menorrhagia-is managed with surgical procedures like ablation, myomectomy or uterine artery embolization or, more recently, by pharmacotherapy [6,22]. The available treatments for UFs, including hysterectomy, myomectomy, embolization, and gonadotropin-releasing hormone (GnRH) agonists, are effective but are recommended in more advanced stages of the disease, especially since they are neither low-cost nor free of risk for adverse events [25,26]. Ulipristal acetate (UPA), a selective progesterone receptor modulator (SPRM), is the most common UF pharmacological treatment [6,22,26-28]. Clinical trials have demonstrated that UPA is effective for controlling UF-related excessive uterine bleeding and reducing fibroid size $[6,22,26,27]$. Treatment schemes with UPA have recently become the gold standard in modern management of UFs [27]. In those schemes, UPA is administered as first-line therapy to prepare UFs for surgery or, in case of good response, to lead to a condition when surgical treatment is no longer necessary [6,29]. However, UPA is relatively expensive and not accessible to everyone, nor is it a substance which can be widely used in prevention [2,22]. In spite of the ongoing research, the currently available pharmacological therapies are short-term, to avoid the risk of chronic hormonal therapy, and are accompanied by long-term adverse side effects. 
One of the major problems associated with UFs is that they are understudied, and therefore, much research is needed in this field $[25,30]$. The development of UFs is multi-factorial in origin, thus specific methods of prophylaxis are currently unavailable. Various recent attempts to create an inexpensive, safe, and effective drug for the prevention and treatment of UFs are still in the early stages of the process [31]. Still, several treatments and prophylactic methods can be used in this endeavor [31]. Current findings suggest that substances contained in green tea [32], vitamin D [25,33], elagolix [34], paricalcitol [35], gestrinone [36], and others may become future preparations for chronic treatment with minimal or moderate side effects. Similar concepts are discussed in an attempt to create a specific method of prophylaxis of UFs in high-risk subjects $[14,25,37]$. High costs and low efficacy are the key points in UF therapy. If more such substances are known, it will be possible to investigate them further (new dosages and schemes), and combine their effect with the known agents to achieve better performance. This, in turn, may have a great impact upon the health of millions of women in the future.

This publication presents current data about lesser-known substances which may have a beneficial effect on the treatment or prophylaxis of UFs and can be administered orally, serving as an alternative to (or complement) surgery or SPRMs.

\section{Materials and Methods}

This article presents an up-to-date review of publications regarding the current role of alternative agents in UF treatment and prophylaxis. A literature search was conducted in PubMed of the National Library of Medicine using the following key words: "uterine fibroid", "pharmacotherapy", "vitamin D", "vitamin D analog", "paricalcitol", "gestrinone", "elagolix", "aromatase inhibitor", "epigallocatechin gallate", "green tea", "curcumin", and "cabergoline". The above keywords were selected to reflect possible oral agents in the prophylaxis and therapy of UFs. During our search, we combined the key words into pairs, which resulted in: "uterine fibroid" and "pharmacotherapy" - 1694 publications; "uterine fibroid" and "vitamin D" — 40 publications; "uterine fibroid" and "vitamin D analog"-2 publications; "uterine fibroid" and "paricalcitol"2 publications; "uterine fibroid" and "gestrinone"-19 publications; "uterine fibroid" and "elagolix" 1 publication; "uterine fibroid" and "aromatase inhibitor" -73 publications; "uterine fibroid" and "epigallocatechin gallate" -7 publications; "uterine fibroid" and "green tea" -8 publications; "uterine fibroid" and "curcumin" -4 publications; "uterine fibroid" and "cabergoline" -4 publications. If the search was duplicated the papers were excluded. The aim of the review was to critically evaluate the current data about lesser-known substances which might have a serious impact on UFs and UF-related symptoms and which can be administered orally. The results of the available studies in English, published up to October 2017, have been discussed in this article. Additional important and impactful articles and reviews were considered, when relevant. Articles were excluded if they were published in languages other than English. After reviewing the titles and abstracts, approximately 150 full articles have been evaluated.

\section{Discussion}

\subsection{Vitamin D}

The least studied factors which affect the risk for UF occurrence are related to lifestyle, diet, nutrition, or place of residence. This can be the gateway to effective prevention of UFs. Vitamin D is the part of the fat-soluble steroid compound group which exerts comprehensive action on the human body [38]. Sunlight exposure is the main source of vitamin D for humans [39]. This vitamin can also be extracted from diet or food supplements. However, very few natural foods contain vitamin D in the appropriate amount. Marine fish, fish oils, and fortified food are among the best sources of vitamin D [40]. 
Vitamin D is believed to reduce the risk for chronic illnesses and malignancies [38,41,42], and has a potent immunomodulatory function. Vitamin D receptor (VDR) is expressed in almost all cells of the immune system where their function is regulated [43,44]. Vitamin D regulates cell proliferation and differentiation, inhibits angiogenesis, and stimulates apoptosis $[33,45]$. Vitamin D deficiency is believed to be a major risk factor in the development of UFs [14,33,37,46]. According to the recent literature reports, mean 25-hydroxyvitamin $\mathrm{D}(25(\mathrm{OH}) \mathrm{D})$ levels are significantly lower in women with UFs as compared to controls $[47,48]$. The same was confirmed in African-Americans, who are more likely to present vitamin D deficiency and UFs [49]. Three main studies on reduced serum vitamin D levels in women with UFs have revolutionized the approach in this field and have unambiguously targeted research for the upcoming years $[46,50,51]$.

New research revealed that a protective effect of vitamin D on UFs is highly likely. VDR is expressed in both, myometrial and tumor tissues [52]. A correlation between low 25(OH)D serum levels and as increased risk for developing UFs was evaluated [14,33,46,51]. According to in vitro experiments, UF cells are highly sensitive to the growth-inhibiting effect of the active form of vitamin D. In those studies, vitamin D induced apoptosis in cultured human UF cells through the downregulation of proliferating cell nuclear antigen (PCNA), cyclin-dependent kinase 1 (CDK1), and B-cell lymphoma-2 (BCL2) and suppressed catechol-O-methyltransferase (COMT) expression and activity [31,52-54] (Figure 1).

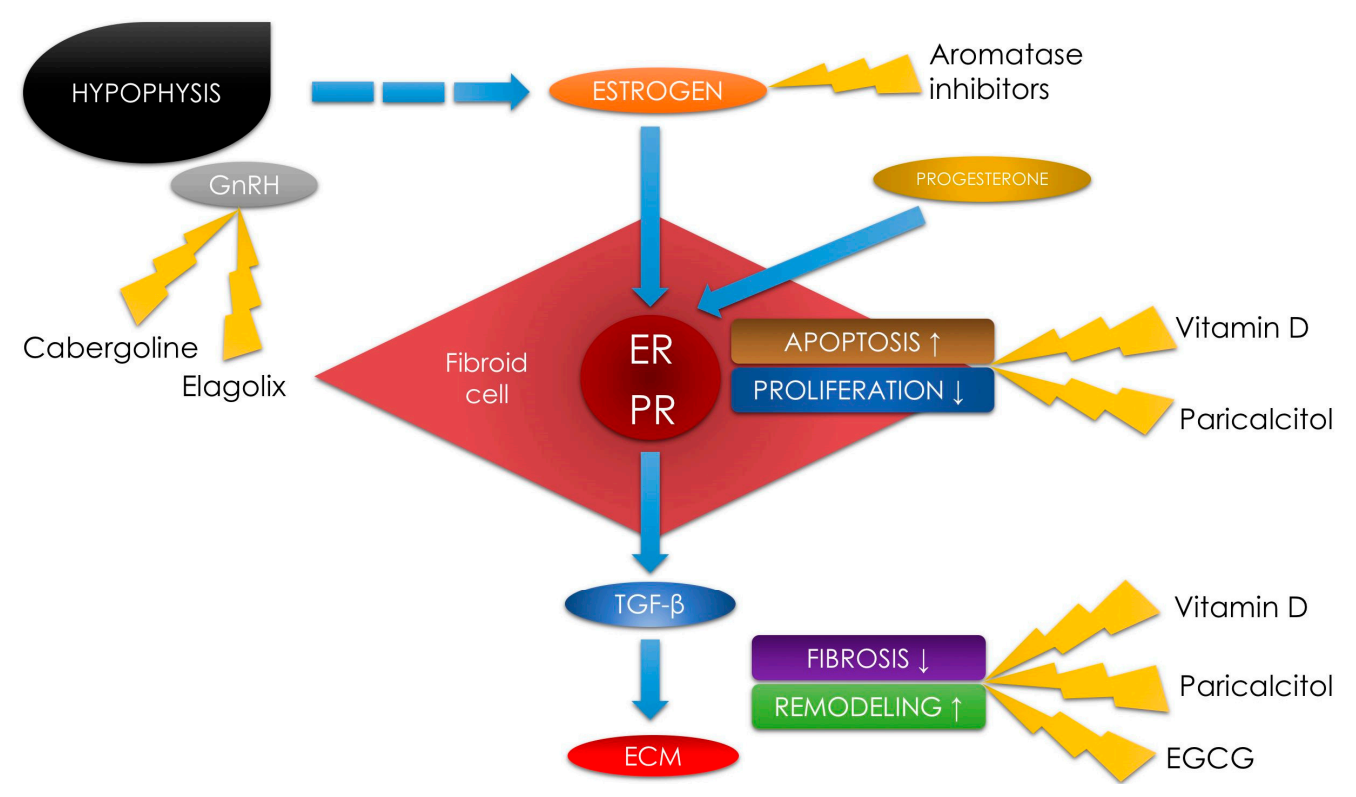

Figure 1. Schematic diagram of uterine fibroid pathophysiology with places for potential use of an alternative agent therapy. Gonadotropin-releasing hormone (GnRH), estrogen receptor (ER), progesterone receptor (PR), transforming growth factor beta (TGF- $\beta$ ), extracellular matrix (ECM), epigallocatechin gallate (EGCG).

In a study by Halder et al., UFs in rats have diminished in size under the influence of this vitamin on the transforming growth factor beta 3 (TGF- $\beta 3$ ) pathway, as vitamin D reduces the TGF- $\beta 3$-induced fibrosis [55]. In a different study, Halder et al. proved that administration of 1,25-dihydroxyvitamin $D$ reduced the expression of type I collagen and fibronectin in UFs [56]. In our recent study, we also found that vitamin D might play a role in decreasing TGF- $\beta 3$ levels in women [14,21] (Figure 1).

Vitamin D toxicity is very rare [41]. The recommended level of vitamin D is defined as a 25(OH)D value of more than $30 \mathrm{ng} / \mathrm{mL}$ [57]. According to the summarized supplementation guidelines developed in 2017 (7000 international units (IU)/day or 50,000 IU/week), deficiency may be remedied by adequate supplementation [58]. Vitamin D supplementation and sunlight exposure are the two main measure for prevention of a wide spectrum of disorders, including UFs [59,60]. 
Our study emphasizes the need for new clinical trials to assess the actual effectiveness of vitamin D in UF therapy. The next step should be a properly constructed, randomized clinical trial. Vitamin D seems to be a promising, safe, effective, and low-cost treatment of UFs. In cases of positive observations, vitamin D preparations could become a new generation of anti-UF drugs, with the additional beneficial pleiotropic effect. Additional skeletal (bones and ligaments) and extra-skeletal (other organs and overall homeostasis) advantages support the use of vitamin D as a prophylactic agent $[25,38,58]$. Further data are needed to fully comprehend the exact role of vitamin D in the pathophysiology of UF. To the best of our knowledge, there are still no randomized controlled trials (RCTs) on this subject, the main reason for that being lack of on the cut-off thresholds for vitamin D deficiency, optimal levels and dosage. However, it seems that the near future will finally bring the consensus [58].

\subsection{Vitamin D Analogs-Paricalcitol}

Due to the potentially adverse or even toxic effects of vitamin D in very high concentrations, consideration should be given to possible alternatives [35]. Vitamin D analogs are already present on the pharmaceutical market and their possible beneficial effects are intriguing. Paricalcitol (a wellknown vitamin D analog) is a selective VDR activator which is registered and used in secondary hyperparathyroidism [61]. According to Bouillon et al., paricalcitol has less calcemic activity than vitamin D and might be a new option in modern therapy [62]. Paricalcitol can cause electrolyte abnormalities like hypercalcemia and hyperphosphatemia, and is contraindicated in patients who use digoxin, thiazide diuretics, and ketoconazole [63]. Paricalcitol has a proven inhibitory effect on cell proliferation and fibrosis $[35,64]$. It has also been found to reduce the increase of the extracellular matrix (ECM) accumulation in the peritoneum of dialyzed patients [65]. In a study by Stavenuiter et al., the authors concluded that the immunomodulatory effects of paricalcitol have beneficially contributed to the development of ECM (limiting its thickening), and that VDR activation can partly increase the kidney filtration rate due to limitation of angiogenesis and thickening of ECM [65].

Vitamin D reduces inflammation and fibrosis by VDR activation [66,67]. According to a study by Protic et al., cytokines play a key role in inflammation and tissue remodeling regulation, indicating that they may be responsible for UF-associated symptoms such as pain or infertility [45]. TGF- $\beta$ (mainly TGF- $\beta 3$ isoform) plays one of the major roles in UF-related fibrosis $[14,54,68,69]$. In their study, Oblak et al. demonstrated a significant decrease in TGF- $\beta$ serum concentrations in transplant recipients who received paricalcitol as compared to controls [66]. Another study by Gonzales-Mateo et al., showed that the use of paricalcitol strongly reduced peritoneal interleukin (IL)-17 levels, which might correlate with lower peritoneal membrane deterioration and lower fibrotic response in the peritoneum in mice models [44]. As for the relevance of the abovementioned studies to UF therapy, UFs consist largely of ECM with embedded cells and excessive ECM production is considered to be one of the mechanisms of UF formation [70]. The ECM which builds the uterus is much more abundant than properly functioning myometrial tissue [71]. Matrix metalloproteinases (MMPs) are calcium-dependent endopeptidases which degrade the structure and rebuild the ECM [72]. ECM undergoes a continuous and balanced reconstruction process which contributes to the maintenance of its proper amount and hardness. Matrix enzymes are regulated by special inhibitors of ECM metalloproteinases (tissue inhibitor of metalloproteinases (TIMP)) [73] (Figure 1). Recent research has demonstrated that vitamin D increased TIMP expression in uterine myometrium [56].

In conclusion, paricalcitol effectively reduces the proliferation of human leiomyoma cell cultures, reduces fibroid tumor volumes, and induces apoptosis in UFs [35]. In our opinion, paricalcitol may be an effective agent in UF therapy. It has great potential as an effective drug or co-drug for the conservative treatment of UFs. However, advanced clinical trials are necessary to confirm its efficacy and safety [35]. To the best of our knowledge, there have been no RCT on the use of paricalcitol in UF therapy. 


\subsection{Green Tea Extract-Epigallocatechin Gallate}

Tea is one of the most popular beverages in the world. Green tea is made from Camellia sinensis leaves [74,75]. It originated in China, but later spread to many parts of Asia. Green tea contains several catechins with treatment potential: epigallocatechin gallate (EGCG), epigallocatechin (EGC), epicatechin gallate (ECG), epicatechins, and flavonols [76].

Various researches suggested that polyphenols have antioxidative, anticarcinogenic, and anti-inflammatory effects in humans $[75,77]$. Currently, EGCG, an ester of epigallocatechin and gallic acid, is one of the most investigated green tea polyphenols in medicine. The effect of EGCG was studied in oncology, where it presented beneficial effects [78,79]. EGCG is an anti-obesity and anti-adipogenic agent due to its activity in the adipogenic differentiation of mice mesenchymal stem cell inhibition [80]. One of the key pathways in this process is based on the gamma protein blocking activity of EGCG human peroxisome proliferator activated receptor gamma (PPAR $\gamma)$ [80]. In non-acute fatty liver disease animal models, EGCG reduced the concentration of pro-fibrotic and pro-inflammatory factors in several different pathways [81]. In studies on pulmonary fibrosis, EGCG significantly inhibited fibroblast activation and ECM accumulation by blocking the TGF- $\beta 1$ signaling pathway [82].

The question arises whether adequate amounts of green tea might exhibit protective effect against UFs. In an interesting study by Matsuzaki et al., EGCG was found to inhibit proliferation and invasion of endometrial implants in animals [83]. In molecular findings, EGCG reduced the TGF- $\beta$-dependent mRNA expression of fibrosis mediators [83] (Figure 1). These authors concluded that EGCG might be a potential candidate in the treatment of endometriosis [83]. The only problem with this agent is its low bioavailability in natural sources [83-85], but several studies regarding the improved derivatives, analogs, or prodrugs of EGCG have demonstrated positive and promising results [86,87].

The effectiveness of EGCG has been studied in UF pathophysiology, and the results are more than interesting [72]. Some authors believe that it might be a new weapon in the battle against UFs $[22,88]$. EGCG was found to inhibit proliferation and reduce the volume of UF tumors in mice [89]. Various studies have demonstrated its effect on inhibition of proliferation and induction of apoptosis in human UF cells [32]. In those studies, EGCG was a modulation agent in the proliferation, transformation, and inflammation in UF tumors [32,50]. The pathophysiological pathways proving EGCG modulation potential included PCNA, CDK1 and BCL2 (same as in vitamin D) [31]. Studies by Zhang et al., demonstrated that UFs in mice and human UF cell colonies were shrinking under the influence of EGCG [32,89] (Figure 1). Roshdy et al. evaluated the oral use of EGCG in women with symptomatic UFs and the results are highly encouraging. Women who received $800 \mathrm{mg}$ of $45 \%$ EGCG for 4 months had a significant reduction of the total fibroid tumor burden and alleviation of symptom severity as compared to controls [88]. More recently, Ahmed et al. presented interesting data about potent prodrugs and analogs of EGCG which resulted in enhanced bioavailability, stability, and antiproliferative and antifibrotic properties. These findings enable us to discern that green tea extract might have found its place in UF management. Those authors are planning broader studies regarding these drugs which, in our opinion, might be revolutionary [87]. If the results about long-term safety and efficacy are positive, EGCG might become the new quality treatment in UF management [87]. As EGCG is now available as a dietary supplement [90], it would also be interesting to investigate the possible effects of combining it with vitamin $\mathrm{D}$ or paricalcitol.

The literature lack data on safe dose levels of pure EGCG. According to the available sources, hepatotoxicity was observed in animal studies with the use of high doses of EGCG. Ramachandran estimated the maximum tolerable dose of EGCG at $67.8 \mathrm{mg} / \mathrm{kg}$ orally (in the course of two weeks) [91].

In our opinion, available data suggest that EGCG has a very high potential to become an alternative agent in the prophylaxis or anti-UF therapy, but RCTs on this subject are unavailable.

\subsection{Elagolix}

GnRH agonists are highly effective drugs in the management of symptomatic endometriosis [92,93], as well as in UFs [2,6]. Alas, they can cause severe hypoestrogenic effects, such as vasomotor symptoms 
(e.g., hot flashes), which will limit the treatment duration or cause the patient to discontinue the therapy due to the reduced QoL [93]. The treatment of benign gynecological diseases does not require full estrogen suppression to partly or even fully reduce the symptoms [93].

Elagolix is a potent and selective non-peptide antagonist of the GnRH receptor [94,95]. It is one of very few (with relugolix [96], and OBE2109 [97]) GnRH antagonists which can be administered orally, and its administration in proper doses suppresses the reproductive endocrine axis in healthy premenopausal women [98]. According to several studies, elagolix is superior to the currently available GnRH agonists and antagonists due to its manageability, rapid onset of action, good bioavailability, rapid reversibility, and minor side effects [93,98]. Very recently $\mathrm{Ng}$ et al. published their data supporting elagolix administration in premenopausal women with sex-hormone dependent diseases [93]. In their opinion, elagolix might be useful in modulating the pituitary-ovarian axis by dose-dependent partial or full suppression [93] (Figure 1). Studies about the intense pain associated with endometriosis demonstrated that elagolix has good efficacy and tolerability. Very recently, Taylor et al. studied 872 women and found that elagolix has great potential as an important treatment option for women suffering from endometriosis. In this study, women who received elagolix had significantly lower scores for dysmenorrhea and non-menstrual pelvic pain than placebo controls [99].

Even if its activity and influence have been tested mostly in endometriosis $[95,99]$, there are also studies about the use of elagolix in UF management. Recently, Archer et al. presented their results regarding different doses of elagolix in heavy menstrual bleeding [34]. Elagolix reduced heavy menstrual bleeding symptoms in women with UFs. Optimal results were obtained using the dose of $300 \mathrm{mg}$ twice per day [34]. These authors observed hypoestrogenic side effects such hot flashes (most frequent), nausea, or headache in some patients, but they were significantly reduced by the use of low-dose estrogen add-back therapy [34]. They concluded that elagolix is a candidate for becoming the new medication in the chronic treatment of clinically symptomatic UFs and should be moved to the next phase of the clinical trials [34]. Phase III studies determined that elagolix achieves its primary endpoints in endometriosis, while adverse events during its use were described as mild to moderate (the most common ones are headache, nausea and anxiety) [100]. Data about its toxicity remains limited.

The pharmaceutical company currently undertaking elagolix clinical trials intends to submit elagolix as a drug in endometriosis therapy to the United States Food and Drug Administration in 2017 [101]. Phase III clinical trials of elagolix in UF therapy are underway [101]. Even if this new GnRH antagonist is well tolerated, much remains to be discovered. We need further studies in larger numbers for longer time periods to gain additional information about the efficacy, tolerability, and compliance of elagolix [34,100].

\subsection{Aromatase Inhibitors}

Aromatase is one of the major enzymes responsible for estrogen synthesis. It can be found in various tissues, including gonads, adipocytes, blood vessels, and the nervous, integumentary, and skeletal systems, as well as endometrial implants, UF tumors, or gynecological cancers [102,103]. Aromatase inhibitors (AIs) decrease the production of estrogens by blocking or inactivating aromatase. AIs are a class of drugs which demonstrate the antiestrogenic effect (Figure 1). The most well-known AIs are anastrozole, letrozole, and fadrozole. They are mainly used in the treatment of gynecological cancers (breast or endometrial cancer) [104], to suppress estrogen production [104], and to treat endometriosis [105-107] or infertility (induction of the ovulation) [107]. AIs have good efficacy, but they can cause common side effects, such hot flashes, bone loss, mood swings, vaginal dryness, ovarian cyst formation, or body pain [108]. The use of AIs in premenopausal women can rise the plasma estrogens levels by the stimulation of gonadotropins $[109,110]$. In peri- or post-menopausal women, estrogens are mainly produced in the peripheral tissues (e.g., adipocytes). Using AIs in this patient group would decrease estrogen levels in both, plasma and tissues [109,110]. Postmenopausal 
women are already exposed to a low-hormone environment, and the use of AIs can lead to better results in the treatment of hormone-dependent diseases [111].

There are several studies about the effect of AIs on UF and UF-related symptoms [108]. Notably, UF tissue expresses aromatase in higher amounts than normal myometrial tissue [112], and aromatase has decreased expression in Japanese and Caucasian subjects as compared to African-Americans, who have a higher rate of UFs [113]. On the basis of these findings, we can expect better results with the use of AIs in African-American populations [114]. Anastrozole has been described as an agent which shrinks UF tumors and reduces the clinical symptoms in post- [115] and peri-menopausal women without serious adverse events [116]. AIs were also found to have an advantage in the rapid onset of action $[115,116]$. In the study by Varelas et al., 3 month-use of anastrazole reduced mean UF volume by almost two-thirds, and these authors concluded that the use of AIs should be proposed to all women who want to avoid risky surgery [117]. In 2003, Shozu et al. published studies where AIs were shown to reduce UF size even up to $70 \%$ in just a 2-month period, with fewer side effects than GnRH analog therapy [22,118]. In an RCT comparing the effect of letrozole and triptorelin by Parsanezhad et al., letrozole presented better uterine volume reduction than the GnRH analog $(45.6 \%$ vs. $33.2 \%$, respectively) [109]. In this study, approximately $96 \%$ of patients in the triptorelin group reported related vasomotor symptoms, whereas in the AI group it was a rare finding [109]. In their review article, Shozu et al. concluded that certain doses of AIs can fully block the estrogen production in UF tumors, whereas ovarian production of estrogen would continue, but at reduced levels [118]. In this situation, UF tumors would shrink, and estrogen deficiency symptoms would be mild and tolerable [118]. In the case of concomitant symptoms during AI therapy, some authors advise the use of add-back treatment of GnRH analogs, estrogens, or progestins to prevent the increase in gonadotropin secretion and related symptoms [119].

A Cochrane review by Song et al., failed to present significant data which would support a wider clinical use of AIs in UF-related bleeding [120]. In 2013, reviewers concluded that the evidence of AI effectiveness and safety was insufficient to allow any conclusions to be drawn. In recent years, more studies about the role of AIs in the management of UFs have been published, and we hope that future systematic reviews and meta-analysis will gave us more answers about the use of AI in UF therapy [120]. In a study conducted by Duhan et al., a 12-week letrozole therapy reduced the mean UF volume by $52.5 \%$ in premenopausal women with clinically symptomatic tumors [121]. What is even more interesting, the side effects were mild (mostly hot flashes), and no significant effects were observed on lipid profiles and steroid serum levels [121]. Similar results were obtained by Sayyah-Melli et al. [122], who mixed letrozole with cabergoline. In their study, 12 weeks of treatment with letrozole with and without cabergoline improved the size and volume of UFs without significant differences between the study groups. Both groups were comparable for the remaining minor side effects [122]. In an interesting study from 2014, administration of letrozole and norethindrone acetate in patients with large UFs decreased the mean operative time by $13 \mathrm{~min}$, intraoperative blood loss by $190 \mathrm{~mL}$, and suturing time by $10 \mathrm{~min}$ during laparoscopic myomectomy as compared to placebo controls [123]. More recently, in another Italian study, the authors compared preoperative administration of triptorelin, letrozole, and UPA [124]. All medications caused a significant reduction in UF tumor volume, but the highest percentages were observed in the triptorelin and letrozole groups. The use of triptorelin and letrozole significantly decreased the mean hysteroscopy time and absorbed fluid, whereas these variables were insignificant in UPA group and controls [124].

Data about AI use in UF treatment are incomplete and demonstrate the need for more studies using larger sample size, longer time periods, and different doses. These studies will further our knowledge about the potential use of AIs in the treatment and prophylaxis of uterine leiomyomas. As estrogenic pathways are complicated and complex, patients may respond differently. We need to improve the efficacy or safety, perhaps by individualizing the doses and add-backs [9]. In recent studies, the AIs presented themselves as potent drugs in UF management which reduced UF volume 
and improved associated symptoms. Yet, due to limited data and lack of blinded trials, the use of AIs in prevention or early therapy of UFs remains debatable.

\subsection{Cabergoline}

Cabergoline is an ergot derivative and is a potent dopamine receptor agonist. Its overdose might cause nasal congestion, syncope, or hallucinations [125]. Cabergoline has an inhibitory effect on the secretion of GnRH, which may be the basis of its anti-UF effect $[114,126]$ (Figure 1). Clinical data regarding the use of cabergoline in UF therapy are very limited. In a study by Sayyah-Melli et al., $0.5 \mathrm{mg}$ of cabergoline per week had the same effect as $3.75 \mathrm{mg}$ of diphereline (GnRH analog) per month on the reduction of UF volume [127]. Additionally, cabergoline presented a safer pharmacological profile, with fewer adverse drug reactions [127]. In another study, also conducted by Sayyah-Melli, cabergoline was added as a co-drug to letrozole to evaluate its synergic effect in UF therapy [122]. In this study, the addition of cabergoline did not significantly change the drop in UF volume, but caused more women to report a headache as an adverse reaction [101]. Finally, an Iranian study on 51 women showed that administration of cabergoline significantly reduced UF-related symptoms. In this study, women who received $0.5 \mathrm{mg}$ of cabergoline daily for 3 months had decreased pelvic pain, reduced bleeding, and a lower volume of UFs as compared to controls [128].

According to abovementioned data, cabergoline might find its place in the treatment of specific groups of women with clinically symptomatic UFs, but we need more studies which would examine its safety and efficacy [126]. No current RCTs about the use of cabergoline in UF management are available.

\subsection{Others}

We mentioned the top six current alternative agents in UF therapy. There are also other substances which might have an impact in this field. Unfortunately, their trial data and available evidence are limited. We will attempt to briefly explain each of these substances.

Combined oral contraception (COC) has a well-documented efficacy in case of excessive uterine bleeding [129]. The bleeding often accompanies UFs and is in fact UF-dependent [130]. COC is a common first-choice therapy among the gynecologists in women with such complaints. The results of the ESHRE (European Society of Human Reproduction and Embryology) group demonstrated that the use of COC before the age of 17 might have a weak association with UF occurrence [129]. According to a study by Qin et al., COC does not have a significant influence on UF tumor growth and occurrence [131]. Some clinical trials have confirmed that COCs containing estradiol valerate and dienogest are in fact effective in treating excessive bleeding. However, they investigated patients without organic pathologies such as UFs [132]. Current data on the efficacy of COC in UF-therapy are limited.

Gestrinone is a synthetic steroid with mixed progestogenic and antiprogestogenic effects, with some androgenic and antiestrogenic activity, used in gynecology [133]. It has an inhibitory effect on the pituitary gland and is comparable to danazol in its function [134]. According to Zhu et al., it inhibits growth of UFs via its antagonistic effect on the estrogen and progesterone receptors [36]. In various studies by Coutinho et al., administration of gestrinone reduced UF tumor volume and uterine bleeding [135-137]. The side effects of gestrinone were as follows: weight gain and androgenic features such as decreased breast size, acne, seborrhea, and hirsutism [136]. In light of rather limited beneficial effects of using gestrinone in UF therapy, no RCTs comparing gestrinone and other agents or even a placebo are currently available [114].

Curcumin is a yellow substance produced by some plants. It is used as food seasoning, cosmetic ingredient, or herbal supplement. Curcumin is a diarylheptanoid belonging to the curcuminoid family (natural phenols), which has anti-inflammatory, antioxidative [138], and anti-cancer activities, including the inhibition of initiation, progression, invasion, and metastasis formation [139]. According to the available data, curcumin might be applicable in therapy but its low bioavailability and solubility, as well as its rapid metabolism create a challenge [139]. A study by Shishodia et al., 
revealed that curcumin might inhibit proliferation and fibrosis and regulate apoptosis in mantle cell lymphoma $[90,140]$. In a study by Malik et al., curcumin demonstrated an inhibitory effect on UF cell proliferation and production of ECM [141]. This inhibitory effect on UF cells was also described by Tsuiji et al., who presented data that curcumin suppresses UF cell proliferation via the activation of PPAR $\gamma$ and decreased proteoglycan expression in ECM [142]. In our opinion, the available data do not support the wider use of curcumin in UF therapy and additional evidence is needed.

SB525334 is a potent and selective inhibitor of TGF- $\beta$ receptor I (ALK5) [143]. This agent has been found to prevent pulmonary and renal fibrosis [143]. The TGF- $\beta$ pathway is one of the most important pathways in UF biology [1]. Some authors believe that SB525334 might be a new high-quality treatment in UF therapy [108]. According to a study by Laping et al., treatment with this agent decreases the incidence, number, and size of UF tumors in a mutant rodent model [144]. Due to incomplete data, further studies are necessary to prove that SB525334 might be useful in UF therapy.

Various literature reports also demonstrated that non-steroidal anti-inflammatory drugs (NSAIDs) can be effective in reducing heavy menstrual bleeding, due to their influence on the endometrial cyclooxygenase levels [114,145]. These drugs were widely tested in abnormal uterine bleeding, but there is no sufficient data to recommend them in women with UFs and other symptoms as they do not exert any influence on fibroid volume [114]. Very recently, Gao et al. published their data about the effect of acetylsalicylic acid on UF cells. Their results suggested that aspirin inhibits UF cell growth by the regulation of K-Ras pathways [146]. While interesting, nothing else is known in this area. We hope that we will receive more data about the potential usefulness of aspirin in the prophylaxis or UF therapy very soon.

One of the last substances of note is pirfenidone, a pyridine molecule used as an antifibrotic agent $[147,148]$ in the treatment of pulmonary fibrosis [148]. Studies about pirfenidone and UFs demonstrated that pirfenidone was an effective inhibitor of myometrial and UF cell proliferation, and that it reduced ECM mRNA levels [147]. We cannot recommend it as a standard treatment due to lack of published data.

Finally, there are several studies regarding the potential role of Ro 41-0960, a synthetic COMT inhibitor [149] and tocopherol analogs in the treatment of UFs [150] but these agents need more evidence.

\section{Conclusions}

UFs constitute a serious health problem for many women of reproductive age, as well as those approaching, or actively in, menopause. Prophylaxis of UFs is practically non-existent, while treatment is often costly and expensive. Surgery is standard in symptomatic UF treatment. UPA has been available for several years. Other forms of treatment are not accepted by patients. In the case of more effective agents, the main problem is the chronic use of drugs and the related side effects. In the case of other agents, their poor effectiveness remains the greatest issue. In our opinion, additional solutions are necessary to create appropriate schemes of pharmacological treatment for different groups of women (obese or non-obese, Caucasian or African-American, pre- or post-menopausal, etc.).

Early prevention and treatment of UFs in women from high-risk groups should be our priority. Innovative forms of UF management are under intensive investigation and may be promising options in the near future. There are several studies about the role of the abovementioned agents in UF prophylaxis and therapy in humans. Many of them evaluated vitamin D, paricalcitol, EGCG, elagolix, AIs, and cabergoline and deemed them safe and effective. The next step in such projects should be properly constructed RCTs, carried out by successive phases. However, the agents on the current list had only one registered trial [101], or none at all. In the case of further positive observations, these agents could become the new generation of drugs in the treatment of UFs, even in the era of UPA.

Perhaps the future solution will be to identify high-risk groups before the onset of UFs and implement preventive methods on the basis of the presented literature. Vitamin D and green tea extract might be optimal in such cases. Recent attempts to create a new, cheap, safe, and effective drug for 
the treatment of UFs remain in the very early stages, and their success has not been yet determined. Recent findings suggest that substances such as paricalcitol and elagolix may be the formulas for the future as they have minimal or moderate side effects and high levels of efficacy in UF therapy.

Acknowledgments: This study was funded by The Centre of Postgraduate Medical Education. Grant number 501-1-21-27-17.

Author Contributions: Michał Ciebiera, Krzysztof Łukaszuk, Błażej Męczekalski and G.J. designed the review. Michał Ciebiera, Krzysztof Łukaszuk, Błażej Męczekalski, Magdalena Ciebiera, Cezary Wojtyła, Aneta Słabuszewska-Jóźwiak and Grzegorz Jakiel analyzed the data and wrote the paper. Michał Ciebiera and Magdalena Ciebiera draw the figure. Michał Ciebiera Krzysztof Łukaszuk, Błażej Męczekalski, and Grzegorz Jakiel supervised the work and accepted the final version of the manuscript.

Conflicts of Interest: Michał Ciebiera, Aneta Słabuszewska-Jóźwiak and Grzegorz Jakiel have received personal fees from Gedeon Richter not related to this work. The Gedeon Richter had no role in the design of the study; in the collection, analyses, or interpretation of data; in the writing of the manuscript, and in the decision to publish the results.

$\begin{array}{ll}\text { Abbreviations } & \\ \text { 25(OH)D } & \text { 25-hydroxyvitamin D } \\ \text { AI } & \text { aromatase inhibitor } \\ \text { ALK5 } & \text { transforming growth factor- } \beta \text { type 1 receptor } \\ \text { BCL } & \text { B-cell lymphoma } \\ \text { CDK } & \text { cyclin-dependent kinase } \\ \text { COMT } & \text { catechol-O-methyltransferase } \\ \text { ECG } & \text { epicatechin gallate } \\ \text { EGC } & \text { epigallocatechin } \\ \text { EGCG } & \text { epigallocatechin gallate } \\ \text { ER } & \text { estrogen receptor } \\ \text { GnRH } & \text { gonadotropin-releasing hormone } \\ \text { MMP } & \text { matrix metalloproteinase } \\ \text { mRNA } & \text { messenger RNA } \\ \text { PCNA } & \text { proliferating cell nuclear antigen } \\ \text { PPAR } & \text { peroxisome proliferator-activated receptor } \\ \text { PR } & \text { progesterone receptor } \\ \text { QoL } & \text { quality of life } \\ \text { RCT } & \text { randomized control trial } \\ \text { SPRM } & \text { selective progesterone receptor modulator } \\ \text { TGF- } \beta & \text { transforming growth factor beta } \\ \text { TIMP } & \text { tissue inhibitor of metalloproteinase } \\ \text { UF } & \text { uterine fibroid } \\ \text { UPA } & \text { ulipristal acetate } \\ \text { VDR } & \text { vitamin D receptor } \\ & \end{array}$

\section{References}

1. Bulun, S.E. Uterine fibroids. N. Engl. J. Med. 2013, 369, 1344-1355. [CrossRef] [PubMed]

2. Stewart, E.A.; Laughlin-Tommaso, S.K.; Catherino, W.H.; Lalitkumar, S.; Gupta, D.; Vollenhoven, B. Uterine fibroids. Nat. Rev. Dis. Prim. 2016, 2, 16043. [CrossRef] [PubMed]

3. Al-Hendy, A.; Myers, E.R.; Stewart, E. Uterine fibroids: Burden and unmet medical need. Semin. Reprod. Med. 2017, 35, 473-480. [CrossRef] [PubMed]

4. Parker, W.H. Etiology, symptomatology, and diagnosis of uterine myomas. Fertil. Steril. 2007, 87, 725-736. [CrossRef] [PubMed]

5. Wise, L.A.; Palmer, J.R.; Stewart, E.A.; Rosenberg, L. Age-specific incidence rates for self-reported uterine leiomyomata in the black women's health study. Obstet. Gynecol. 2005, 105, 563-568. [CrossRef] [PubMed]

6. Donnez, J.; Dolmans, M.M. Uterine fibroid management: From the present to the future. Hum. Reprod. Update 2016, 22, 665-686. [CrossRef] [PubMed] 
7. Stewart, E.A. Uterine fibroids. Lancet 2001, 357, 293-298. [CrossRef]

8. Baird, D.D.; Dunson, D.B.; Hill, M.C.; Cousins, D.; Schectman, J.M. High cumulative incidence of uterine leiomyoma in black and white women: Ultrasound evidence. Am. J. Obstet. Gynecol. 2003, 188, $100-107$. [CrossRef] [PubMed]

9. Borahay, M.A.; Asoglu, M.R.; Mas, A.; Adam, S.; Kilic, G.S.; Al-Hendy, A. Estrogen receptors and signaling in fibroids: Role in pathobiology and therapeutic implications. Reprod. Sci. 2017, 24, 1235-1244. [CrossRef] [PubMed]

10. Ishikawa, H.; Ishi, K.; Serna, V.A.; Kakazu, R.; Bulun, S.E.; Kurita, T. Progesterone is essential for maintenance and growth of uterine leiomyoma. Endocrinology 2010, 151, 2433-2442. [CrossRef] [PubMed]

11. Maruo, T.; Ohara, N.; Wang, J.; Matsuo, H. Sex steroidal regulation of uterine leiomyoma growth and apoptosis. Hum. Reprod. Update 2004, 10, 207-220. [CrossRef] [PubMed]

12. Ciarmela, P.; Islam, M.S.; Reis, F.M.; Gray, P.C.; Bloise, E.; Petraglia, F.; Vale, W.; Castellucci, M. Growth factors and myometrium: Biological effects in uterine fibroid and possible clinical implications. Hum. Reprod. Update 2011, 17, 772-790. [CrossRef] [PubMed]

13. Tal, R.; Segars, J.H. The role of angiogenic factors in fibroid pathogenesis: Potential implications for future therapy. Hum. Reprod. Update 2014, 20, 194-216. [CrossRef] [PubMed]

14. Ciebiera, M.; Wlodarczyk, M.; Slabuszewska-Jozwiak, A.; Nowicka, G.; Jakiel, G. Influence of vitamin D and transforming growth factor $\beta 3$ serum concentrations, obesity, and family history on the risk for uterine fibroids. Fertil. Steril. 2016, 106, 1787-1792. [CrossRef] [PubMed]

15. Makinen, N.; Mehine, M.; Tolvanen, J.; Kaasinen, E.; Li, Y.; Lehtonen, H.J.; Gentile, M.; Yan, J.; Enge, M.; Taipale, M.; et al. Med12, the mediator complex subunit 12 gene, is mutated at high frequency in uterine leiomyomas. Science 2011, 334, 252-255. [CrossRef] [PubMed]

16. Heinonen, H.R.; Sarvilinna, N.S.; Sjoberg, J.; Kampjarvi, K.; Pitkanen, E.; Vahteristo, P.; Makinen, N.; Aaltonen, L.A. Med12 mutation frequency in unselected sporadic uterine leiomyomas. Fertil. Steril. 2014, 102, 1137-1142. [CrossRef] [PubMed]

17. Soave, I.; Marci, R. Uterine leiomyomata: The snowball effect. Curr. Med. Res. Opin. 2017, 33, $1909-1911$. [CrossRef] [PubMed]

18. Soliman, A.M.; Margolis, M.K.; Castelli-Haley, J.; Fuldeore, M.J.; Owens, C.D.; Coyne, K.S. Impact of uterine fibroid symptoms on health-related quality of life of US women: Evidence from a cross-sectional survey. Curr. Med. Res. Opin. 2017, 33, 1971-1978. [CrossRef] [PubMed]

19. Soliman, A.M.; Yang, H.; Du, E.X.; Kelkar, S.S.; Winkel, C. The direct and indirect costs of uterine fibroid tumors: A systematic review of the literature between 2000 and 2013. Am. J. Obstet. Gynecol. 2015, 213, 141-160. [CrossRef] [PubMed]

20. Cardozo, E.R.; Clark, A.D.; Banks, N.K.; Henne, M.B.; Stegmann, B.J.; Segars, J.H. The estimated annual cost of uterine leiomyomata in the United States. Am. J. Obstet. Gynecol. 2012, 206, 211.e1-211.e9. [CrossRef] [PubMed]

21. Lee, D.W.; Ozminkowski, R.J.; Carls, G.S.; Wang, S.; Gibson, T.B.; Stewart, E.A. The direct and indirect cost burden of clinically significant and symptomatic uterine fibroids. J. Occup. Environ. Med. 2007, 49, 493-506. [CrossRef] [PubMed]

22. Faustino, F.; Martinho, M.; Reis, J.; Aguas, F. Update on medical treatment of uterine fibroids. Eur. J. Obstet. Gynecol. Reprod. Biol. 2017, 216, 61-68. [CrossRef] [PubMed]

23. Singh, S.S.; Belland, L. Contemporary management of uterine fibroids: Focus on emerging medical treatments. Curr. Med. Res. Opin. 2015, 31, 1-12. [CrossRef] [PubMed]

24. Stewart, E.A. Clinical practice. Uterine fibroids. N. Engl. J. Med. 2015, 372, 1646-1655. [CrossRef] [PubMed]

25. Wu, J.L.; Segars, J.H. Is vitamin D the answer for prevention of uterine fibroids? Fertil. Steril. 2015, 104, 559-560. [CrossRef] [PubMed]

26. Donnez, J.; Donnez, O.; Dolmans, M.M. Safety of treatment of uterine fibroids with the selective progesterone receptor modulator, ulipristal acetate. Expert Opin. Drug Saf. 2016, 15, 1679-1686. [CrossRef] [PubMed]

27. Donnez, J.; Donnez, O.; Courtoy, G.E.; Dolmans, M.M. The place of selective progesterone receptor modulators in myoma therapy. Minerva Ginecol. 2016, 68, 313-320. [PubMed]

28. Biglia, N.; Carinelli, S.; Maiorana, A.; D'Alonzo, M.; Lo Monte, G.; Marci, R. Ulipristal acetate: A novel pharmacological approach for the treatment of uterine fibroids. Drug Des. Dev. Ther. 2014, 8, $285-292$. [CrossRef] 
29. Donnez, J.; Arriagada, P.; Donnez, O.; Dolmans, M.M. Current management of myomas: The place of medical therapy with the advent of selective progesterone receptor modulators. Curr. Opin. Obstet. Gynecol. 2015, 27, 422-431. [CrossRef] [PubMed]

30. Commandeur, A.E.; Styer, A.K.; Teixeira, J.M. Epidemiological and genetic clues for molecular mechanisms involved in uterine leiomyoma development and growth. Hum. Reprod. Update 2015, 21, 593-615. [CrossRef] [PubMed]

31. Sabry, M.; Al-Hendy, A. Innovative oral treatments of uterine leiomyoma. Obstet. Gynecol. Int. 2012, 2012, 943635. [CrossRef] [PubMed]

32. Zhang, D.; Al-Hendy, M.; Richard-Davis, G.; Montgomery-Rice, V.; Rajaratnam, V.; Al-Hendy, A. Antiproliferative and proapoptotic effects of epigallocatechin gallate on human leiomyoma cells. Fertil. Steril. 2010, 94, 1887-1893. [CrossRef] [PubMed]

33. Brakta, S.; Diamond, J.S.; Al-Hendy, A.; Diamond, M.P.; Halder, S.K. Role of vitamin D in uterine fibroid biology. Fertil. Steril. 2015, 104, 698-706. [CrossRef] [PubMed]

34. Archer, D.F.; Stewart, E.A.; Jain, R.I.; Feldman, R.A.; Lukes, A.S.; North, J.D.; Soliman, A.M.; Gao, J.; Ng, J.W.; Chwalisz, K. Elagolix for the management of heavy menstrual bleeding associated with uterine fibroids: Results from a phase 2a proof-of-concept study. Fertil. Steril. 2017, 108, 152-160. [CrossRef] [PubMed]

35. Halder, S.K.; Sharan, C.; Al-Hendy, O.; Al-Hendy, A. Paricalcitol, a vitamin D receptor activator, inhibits tumor formation in a murine model of uterine fibroids. Reprod. Sci. 2014, 21, 1108-1119. [CrossRef] [PubMed]

36. Zhu, Y.; Zhang, T.; Xie, S.; Tu, R.; Cao, Y.; Guo, X.; Zhou, J.; Zhou, X.; Cao, L. Gestrinone inhibits growth of human uterine leiomyoma may relate to activity regulation of ER $\alpha$, Src and P38 MAPK. Biomed. Pharmacother. 2012, 66, 569-577. [CrossRef] [PubMed]

37. Halder, S.; Al-Hendy, A. Hypovitaminosis D and high serum transforming growth factor $\beta-3$ : Important biomarkers for uterine fibroids risk. Fertil. Steril. 2016, 106, 1648-1649. [CrossRef] [PubMed]

38. Holick, M.F. The vitamin D deficiency pandemic: Approaches for diagnosis, treatment and prevention. Rev. Endocr. Metab. Disord. 2017, 18, 153-165. [CrossRef] [PubMed]

39. Holick, M.F. Sunlight and vitamin D for bone health and prevention of autoimmune diseases, cancers, and cardiovascular disease. Am. J. Clin. Nutr. 2004, 80, 1678S-1688S. [PubMed]

40. Parazzini, F.; Di Martino, M.; Candiani, M.; Vigano, P. Dietary components and uterine leiomyomas: A review of published data. Nutr. Cancer 2015, 67, 569-579. [CrossRef] [PubMed]

41. Holick, M.F. Vitamin D deficiency. N. Engl. J. Med. 2007, 357, 266-281. [CrossRef] [PubMed]

42. Nair, R.; Maseeh, A. Vitamin D: The "sunshine" vitamin. J. Pharmacol. Pharmacother. 2012, 3, 118-126. [CrossRef] [PubMed]

43. Bikle, D.D. Vitamin D and immune function: Understanding common pathways. Curr. Osteoporos. Rep. 2009, 7, 58-63. [CrossRef] [PubMed]

44. Gonzalez-Mateo, G.T.; Fernandez-Millara, V.; Bellon, T.; Liappas, G.; Ruiz-Ortega, M.; Lopez-Cabrera, M.; Selgas, R.; Aroeira, L.S. Paricalcitol reduces peritoneal fibrosis in mice through the activation of regulatory T cells and reduction in IL-17 production. PLoS ONE 2014, 9, e108477. [CrossRef] [PubMed]

45. Protic, O.; Toti, P.; Islam, M.S.; Occhini, R.; Giannubilo, S.R.; Catherino, W.H.; Cinti, S.; Petraglia, F.; Ciavattini, A.; Castellucci, M.; et al. Possible involvement of inflammatory/reparative processes in the development of uterine fibroids. Cell Tissue Res. 2016, 364, 415-427. [CrossRef] [PubMed]

46. Paffoni, A.; Somigliana, E.; Vigano, P.; Benaglia, L.; Cardellicchio, L.; Pagliardini, L.; Papaleo, E.; Candiani, M.; Fedele, L. Vitamin D status in women with uterine leiomyomas. J. Clin. Endocrinol. Metab. 2013, 98, E1374-E1378. [CrossRef] [PubMed]

47. Lerchbaum, E.; Rabe, T. Vitamin D and female fertility. Curr. Opin. Obstet. Gynecol. 2014, 26, 145-150. [CrossRef] [PubMed]

48. Oskovi Kaplan, Z.A.; Tasci, Y.; Topcu, H.O.; Erkaya, S. 25-Hydroxy vitamin D levels in premenopausal turkish women with uterine leiomyoma. Gynecol. Endocrinol. 2017, 1-4. [CrossRef] [PubMed]

49. Zhao, G.; Ford, E.S.; Tsai, J.; Li, C.; Croft, J.B. Factors associated with vitamin D deficiency and inadequacy among women of childbearing age in the United States. ISRN Obstet. Gynecol. 2012, 2012, 691486. [CrossRef] [PubMed] 
50. Sabry, M.; Halder, S.K.; Allah, A.S.; Roshdy, E.; Rajaratnam, V.; Al-Hendy, A. Serum vitamin D3 level inversely correlates with uterine fibroid volume in different ethnic groups: A cross-sectional observational study. Int. J. Womens Health 2013, 5, 93-100. [CrossRef] [PubMed]

51. Baird, D.D.; Hill, M.C.; Schectman, J.M.; Hollis, B.W. Vitamin D and the risk of uterine fibroids. Epidemiology 2013, 24, 447-453. [CrossRef] [PubMed]

52. Blauer, M.; Rovio, P.H.; Ylikomi, T.; Heinonen, P.K. Vitamin D inhibits myometrial and leiomyoma cell proliferation in vitro. Fertil. Steril. 2009, 91, 1919-1925. [CrossRef] [PubMed]

53. Sharan, C.; Halder, S.K.; Thota, C.; Jaleel, T.; Nair, S.; Al-Hendy, A. Vitamin D inhibits proliferation of human uterine leiomyoma cells via catechol-O-methyltransferase. Fertil. Steril. 2011, 95, 247-253. [CrossRef] [PubMed]

54. Halder, S.K.; Goodwin, J.S.; Al-Hendy, A. 1,25-Dihydroxyvitamin D3 reduces TGF- $\beta 3$-induced fibrosis-related gene expression in human uterine leiomyoma cells. J. Clin. Endocrinol. Metab. 2011, 96, E754-E762. [CrossRef] [PubMed]

55. Halder, S.K.; Sharan, C.; Al-Hendy, A. 1,25-Dihydroxyvitamin D3 treatment shrinks uterine leiomyoma tumors in the eker rat model. Biol. Reprod. 2012, 86, 116. [CrossRef] [PubMed]

56. Halder, S.K.; Osteen, K.G.; Al-Hendy, A. 1,25-Dihydroxyvitamin D3 reduces extracellular matrix-associated protein expression in human uterine fibroid cells. Biol. Reprod. 2013, 89, 150. [CrossRef] [PubMed]

57. Holick, M.F.; Binkley, N.C.; Bischoff-Ferrari, H.A.; Gordon, C.M.; Hanley, D.A.; Heaney, R.P.; Murad, M.H.; Weaver, C.M.; Endocrine, S. Evaluation, treatment, and prevention of vitamin D deficiency: An endocrine society clinical practice guideline. J. Clin. Endocrinol. Metab. 2011, 96, 1911-1930. [CrossRef] [PubMed]

58. Pludowski, P.; Holick, M.F.; Grant, W.B.; Konstantynowicz, J.; Mascarenhas, M.R.; Haq, A.; Povoroznyuk, V.; Balatska, N.; Barbosa, A.P.; Karonova, T.; et al. Vitamin D supplementation guidelines. J. Steroid Biochem. Mol. Biol. 2017. [CrossRef] [PubMed]

59. Pludowski, P.; Holick, M.F.; Pilz, S.; Wagner, C.L.; Hollis, B.W.; Grant, W.B.; Shoenfeld, Y.; Lerchbaum, E.; Llewellyn, D.J.; Kienreich, K.; et al. Vitamin D effects on musculoskeletal health, immunity, autoimmunity, cardiovascular disease, cancer, fertility, pregnancy, dementia and mortality-A review of recent evidence. Autoimmun. Rev. 2013, 12, 976-989. [CrossRef] [PubMed]

60. Pludowski, P.; Karczmarewicz, E.; Bayer, M.; Carter, G.; Chlebna-Sokol, D.; Czech-Kowalska, J.; Debski, R.; Decsi, T.; Dobrzanska, A.; Franek, E.; et al. Practical guidelines for the supplementation of vitamin D and the treatment of deficits in central europe-recommended vitamin D intakes in the general population and groups at risk of vitamin D deficiency. Endokrynol. Pol. 2013, 64, 319-327. [CrossRef] [PubMed]

61. Al-Baaj, F.; Yadav, P.; Al-Rifai, A. Paricalcitol in secondary hyperparathyroidism and the survival benefit in patients with chronic kidney disease. J. Ren. Care 2011, 37, 75-79. [CrossRef] [PubMed]

62. Bouillon, R.; Verstuyf, A.; Verlinden, L.; Allewaert, K.; Branisteanu, D.; Mathieu, C.; van Baelen, H. Non-hypercalcemic pharmacological aspects of vitamin D analogs. Biochem. Pharmacol. 1995, 50, 577-583. [CrossRef]

63. EMC. Zemplar Soft Capsules 1 mcg. Available online: https://www.Medicines.Org.Uk/emc/medicine/ 20464 (accessed on 16 November 2017).

64. Zhang, Y.; Kong, J.; Deb, D.K.; Chang, A.; Li, Y.C. Vitamin D receptor attenuates renal fibrosis by suppressing the renin-angiotensin system. J. Am. Soc. Nephrol. 2010, 21, 966-973. [CrossRef] [PubMed]

65. Stavenuiter, A.W.; Farhat, K.; Vila Cuenca, M.; Schilte, M.N.; Keuning, E.D.; Paauw, N.J.; ter Wee, P.M.; Beelen, R.H.; Vervloet, M.G. Protective effects of paricalcitol on peritoneal remodeling during peritoneal dialysis. Biomed. Res. Int. 2015, 2015, 468574. [CrossRef] [PubMed]

66. Oblak, M.; Mlinsek, G.; Kandus, A.; Buturovic-Ponikvar, J.; Arnol, M. Effects of paricalcitol on biomarkers of inflammation and fibrosis in kidney transplant recipients: Results of a randomized controlled trial. Clin. Nephrol. 2017, 88, 119-125. [CrossRef] [PubMed]

67. Freundlich, M.; Quiroz, Y.; Zhang, Z.; Zhang, Y.; Bravo, Y.; Weisinger, J.R.; Li, Y.C.; Rodriguez-Iturbe, B. Suppression of renin-angiotensin gene expression in the kidney by paricalcitol. Kidney Int. 2008, 74, 1394-1402. [CrossRef] [PubMed]

68. Arici, A.; Sozen, I. Transforming growth factor- $\beta 3$ is expressed at high levels in leiomyoma where it stimulates fibronectin expression and cell proliferation. Fertil. Steril. 2000, 73, 1006-1011. [CrossRef] 
69. Lee, B.S.; Nowak, R.A. Human leiomyoma smooth muscle cells show increased expression of transforming growth factor- $\beta 3$ (TGF $\beta 3$ ) and altered responses to the antiproliferative effects of TGF $\beta$. J. Clin. Endocrinol. Metab. 2001, 86, 913-920. [CrossRef] [PubMed]

70. Leppert, P.C.; Baginski, T.; Prupas, C.; Catherino, W.H.; Pletcher, S.; Segars, J.H. Comparative ultrastructure of collagen fibrils in uterine leiomyomas and normal myometrium. Fertil. Steril. 2004, 82, 1182-1187. [CrossRef] [PubMed]

71. Sozen, I.; Arici, A. Interactions of cytokines, growth factors, and the extracellular matrix in the cellular biology of uterine leiomyomata. Fertil. Steril. 2002, 78, 1-12. [CrossRef]

72. Dou, Q.; Tarnuzzer, R.W.; Williams, R.S.; Schultz, G.S.; Chegini, N. Differential expression of matrix metalloproteinases and their tissue inhibitors in leiomyomata: A mechanism for gonadotrophin releasing hormone agonist-induced tumour regression. Mol. Hum. Reprod. 1997, 3, 1005-1014. [CrossRef] [PubMed]

73. Brew, K.; Dinakarpandian, D.; Nagase, H. Tissue inhibitors of metalloproteinases: Evolution, structure and function. Biochim. Biophys. Acta 2000, 1477, 267-283. [CrossRef]

74. Beresniak, A.; Duru, G.; Berger, G.; Bremond-Gignac, D. Relationships between black tea consumption and key health indicators in the world: An ecological study. BMJ Open 2012, 2. [CrossRef] [PubMed]

75. Khan, N.; Mukhtar, H. Tea and health: Studies in humans. Curr. Pharm. Des. 2013, 19, 6141-6147. [CrossRef] [PubMed]

76. Forester, S.C.; Lambert, J.D. The role of antioxidant versus pro-oxidant effects of green tea polyphenols in cancer prevention. Mol. Nutr. Food Res. 2011, 55, 844-854. [CrossRef] [PubMed]

77. Kuriyama, S.; Shimazu, T.; Ohmori, K.; Kikuchi, N.; Nakaya, N.; Nishino, Y.; Tsubono, Y.; Tsuji, I. Green tea consumption and mortality due to cardiovascular disease, cancer, and all causes in Japan: The ohsaki study. JAMA 2006, 296, 1255-1265. [CrossRef] [PubMed]

78. Gupta, S.; Ahmad, N.; Nieminen, A.L.; Mukhtar, H. Growth inhibition, cell-cycle dysregulation, and induction of apoptosis by green tea constituent (-)-epigallocatechin-3-gallate in androgen-sensitive and androgen-insensitive human prostate carcinoma cells. Toxicol. Appl. Pharmacol. 2000, 164, 82-90. [CrossRef] [PubMed]

79. Tang, Y.; Zhao, D.Y.; Elliott, S.; Zhao, W.; Curiel, T.J.; Beckman, B.S.; Burow, M.E. Epigallocatechin-3 gallate induces growth inhibition and apoptosis in human breast cancer cells through survivin suppression. Int. J. Oncol. 2007, 31, 705-711. [CrossRef] [PubMed]

80. Javaid, M.S.; Latief, N.; Ijaz, B.; Ashfaq, U.A. Epigallocatechin gallate as an anti-obesity therapeutic compound: An in silico approach for structure-based drug designing. Nat. Prod. Res. 2017, 1-5. [CrossRef] [PubMed]

81. Xiao, J.; Ho, C.T.; Liong, E.C.; Nanji, A.A.; Leung, T.M.; Lau, T.Y.; Fung, M.L.; Tipoe, G.L. Epigallocatechin gallate attenuates fibrosis, oxidative stress, and inflammation in non-alcoholic fatty liver disease rat model through TGF/SMAD, PI3 K/Akt/FoxO1, and NF-kB pathways. Eur. J. Nutr. 2014, 53, 187-199. [CrossRef] [PubMed]

82. Sriram, N.; Kalayarasan, S.; Manikandan, R.; Arumugam, M.; Sudhandiran, G. Epigallocatechin gallate attenuates fibroblast proliferation and excessive collagen production by effectively intervening TGF- $\beta 1$ signalling. Clin. Exp. Pharmacol. Physiol. 2015, 42, 849-859. [CrossRef] [PubMed]

83. Matsuzaki, S.; Darcha, C. Antifibrotic properties of epigallocatechin-3-gallate in endometriosis. Hum. Reprod. 2014, 29, 1677-1687. [CrossRef] [PubMed]

84. Yang, C.S.; Lambert, J.D.; Hou, Z.; Ju, J.; Lu, G.; Hao, X. Molecular targets for the cancer preventive activity of tea polyphenols. Mol. Carcinog. 2006, 45, 431-435. [CrossRef] [PubMed]

85. Kanwar, J.; Taskeen, M.; Mohammad, I.; Huo, C.; Chan, T.H.; Dou, Q.P. Recent advances on tea polyphenols. Front. Biosci. 2012, 4, 111-131. [CrossRef]

86. Chen, D.; Wan, S.B.; Yang, H.; Yuan, J.; Chan, T.H.; Dou, Q.P. Egcg, green tea polyphenols and their synthetic analogs and prodrugs for human cancer prevention and treatment. Adv. Clin. Chem. 2011, 53, 155-177. [PubMed]

87. Ahmed, R.S.; Liu, G.; Renzetti, A.; Farshi, P.; Yang, H.; Soave, C.; Saed, G.; El-Ghoneimy, A.A.; El-Banna, H.A.; Foldes, R.; et al. Biological and mechanistic characterization of novel prodrugs of green tea polyphenol epigallocatechin gallate analogs in human leiomyoma cell lines. J. Cell. Biochem. 2016, 117, 2357-2369. [CrossRef] [PubMed] 
88. Roshdy, E.; Rajaratnam, V.; Maitra, S.; Sabry, M.; Allah, A.S.; Al-Hendy, A. Treatment of symptomatic uterine fibroids with green tea extract: A pilot randomized controlled clinical study. Int. J. Womens Health 2013, 5, 477-486. [CrossRef] [PubMed]

89. Zhang, D.; Al-Hendy, M.; Richard-Davis, G.; Montgomery-Rice, V.; Sharan, C.; Rajaratnam, V.; Khurana, A.; Al-Hendy, A. Green tea extract inhibits proliferation of uterine leiomyoma cells in vitro and in nude mice. Am. J. Obstet. Gynecol. 2010, 202, 289.e1-289.e9. [CrossRef] [PubMed]

90. Bartels, C.B.; Cayton, K.C.; Chuong, F.S.; Holthouser, K.; Arian, S.E.; Abraham, T.; Segars, J.H. An evidence-based approach to the medical management of fibroids: A systematic review. Clin. Obstet. Gynecol. 2016, 59, 30-52. [CrossRef] [PubMed]

91. Ramachandran, B.; Jayavelu, S.; Murhekar, K.; Rajkumar, T. Repeated dose studies with pure epigallocatechin-3-gallate demonstrated dose and route dependant hepatotoxicity with associated dyslipidemia. Toxicol. Rep. 2016, 3, 336-345. [CrossRef] [PubMed]

92. Maggi, R.; Cariboni, A.M.; Marelli, M.M.; Moretti, R.M.; Andre, V.; Marzagalli, M.; Limonta, P. GnRH and GnRH receptors in the pathophysiology of the human female reproductive system. Hum. Reprod. Update 2016, 22. [CrossRef] [PubMed]

93. Ng, J.; Chwalisz, K.; Carter, D.C.; Klein, C.E. Dose-dependent suppression of gonadotropins and ovarian hormones by elagolix in healthy premenopausal women. J. Clin. Endocrinol. Metab. 2017, 102, 1683-1691. [CrossRef] [PubMed]

94. Chen, C.; Wu, D.; Guo, Z.; Xie, Q.; Reinhart, G.J.; Madan, A.; Wen, J.; Chen, T.; Huang, C.Q.; Chen, M.; et al. Discovery of sodium $R$-(+)-4-\{2-[5-(2-fluoro-3-methoxyphenyl)-3-(2-fluoro-6-[trifluoromethyl]benzyl)4-methyl-2,6-dioxo-3,6-dihydro-2H-pyrimidin-1-yl]-1-phenylethylamino\}butyrate (elagolix), a potent and orally available nonpeptide antagonist of the human gonadotropin-releasing hormone receptor. J. Med. Chem. 2008, 51, 7478-7485. [CrossRef] [PubMed]

95. Ezzati, M.; Carr, B.R. Elagolix, a novel, orally bioavailable GnRH antagonist under investigation for the treatment of endometriosis-related pain. Womens Health 2015, 11, 19-28. [CrossRef] [PubMed]

96. Nakata, D.; Masaki, T.; Tanaka, A.; Yoshimatsu, M.; Akinaga, Y.; Asada, M.; Sasada, R.; Takeyama, M.; Miwa, K.; Watanabe, T.; et al. Suppression of the hypothalamic-pituitary-gonadal axis by TAK-385 (relugolix), a novel, investigational, orally active, small molecule gonadotropin-releasing hormone $(\mathrm{GnRH})$ antagonist: Studies in human gnrh receptor knock-in mice. Eur. J. Pharmacol. 2014, 723, 167-174. [CrossRef] [PubMed]

97. ObsEva. OBE2109-Uterine Fibroids. Available online: http://www.Obseva.Com/pipeline/obe2109 (accessed on 16 November 2017).

98. Struthers, R.S.; Nicholls, A.J.; Grundy, J.; Chen, T.; Jimenez, R.; Yen, S.S.; Bozigian, H.P. Suppression of gonadotropins and estradiol in premenopausal women by oral administration of the nonpeptide gonadotropin-releasing hormone antagonist elagolix. J. Clin. Endocrinol. Metab. 2009, 94, 545-551. [CrossRef] [PubMed]

99. Taylor, H.S.; Giudice, L.C.; Lessey, B.A.; Abrao, M.S.; Kotarski, J.; Archer, D.F.; Diamond, M.P.; Surrey, E.; Johnson, N.P.; Watts, N.B.; et al. Treatment of endometriosis-associated pain with elagolix, an oral GnRH antagonist. N. Engl. J. Med. 2017, 377, 28-40. [CrossRef] [PubMed]

100. Perricos, A.; Wenzl, R. Efficacy of elagolix in the treatment of endometriosis. Expert Opin. Pharmacother. 2017, 18, 1391-1397. [CrossRef] [PubMed]

101. Abbvie. AbbVie Presents Pivotal Phase 3 Data on Investigational Treatment Elagolix at the World Congress on Endometriosis. Available online: https://news.Abbvie.Com/news/abbvie-presents-pivotalphase-3-data-on-investigational-treatment-elagolix-at-world-congress-on-endometriosis.Htm (accessed on 16 November 2017).

102. Shozu, M.; Murakami, K.; Inoue, M. Aromatase and leiomyoma of the uterus. Semin. Reprod. Med. 2004, 22, 51-60. [CrossRef] [PubMed]

103. Czajka-Oraniec, I.; Simpson, E.R. Aromatase research and its clinical significance. Endokrynol. Pol. 2010, 61, 126-134. [PubMed]

104. American College of Obstetricians and Gynecologists' Committee on Gynecologic Practice. Committee opinion No. 663: Aromatase inhibitors in gynecologic practice. Obstet. Gynecol. 2016, 127, e170-e174. [CrossRef]

105. Attar, E.; Bulun, S.E. Aromatase inhibitors: The next generation of therapeutics for endometriosis? Fertil. Steril. 2006, 85, 1307-1318. [CrossRef] [PubMed] 
106. Slopien, R.; Meczekalski, B. Aromatase inhibitors in the treatment of endometriosis. Prz. Menopauzalny 2016, 15, 43-47. [CrossRef] [PubMed]

107. Diamond, M.P.; Legro, R.S.; Coutifaris, C.; Alvero, R.; Robinson, R.D.; Casson, P.; Christman, G.M.; Ager, J.; Huang, H.; Hansen, K.R.; et al. Letrozole, gonadotropin, or clomiphene for unexplained infertility. N. Engl. J. Med. 2015, 373, 1230-1240. [CrossRef] [PubMed]

108. Islam, M.S.; Protic, O.; Giannubilo, S.R.; Toti, P.; Tranquilli, A.L.; Petraglia, F.; Castellucci, M.; Ciarmela, P. Uterine leiomyoma: Available medical treatments and new possible therapeutic options. J. Clin. Endocrinol. Metab. 2013, 98, 921-934. [CrossRef] [PubMed]

109. Parsanezhad, M.E.; Azmoon, M.; Alborzi, S.; Rajaeefard, A.; Zarei, A.; Kazerooni, T.; Frank, V.; Schmidt, E.H. A randomized, controlled clinical trial comparing the effects of aromatase inhibitor (letrozole) and gonadotropin-releasing hormone agonist (triptorelin) on uterine leiomyoma volume and hormonal status. Fertil. Steril. 2010, 93, 192-198. [CrossRef] [PubMed]

110. Giannubilo, S.R.; Ciavattini, A.; Petraglia, F.; Castellucci, M.; Ciarmela, P. Management of fibroids in perimenopausal women. Curr. Opin. Obstet. Gynecol. 2015, 27, 416-421. [CrossRef] [PubMed]

111. Davis, S.R.; Lambrinoudaki, I.; Lumsden, M.; Mishra, G.D.; Pal, L.; Rees, M.; Santoro, N.; Simoncini, T. Menopause. Nat. Rev. Dis. Prim. 2015, 1, 15004. [CrossRef] [PubMed]

112. Sumitani, H.; Shozu, M.; Segawa, T.; Murakami, K.; Yang, H.J.; Shimada, K.; Inoue, M. In situ estrogen synthesized by aromatase P450 in uterine leiomyoma cells promotes cell growth probably via an autocrine/intracrine mechanism. Endocrinology 2000, 141, 3852-3861. [CrossRef] [PubMed]

113. Ishikawa, H.; Reierstad, S.; Demura, M.; Rademaker, A.W.; Kasai, T.; Inoue, M.; Usui, H.; Shozu, M.; Bulun, S.E. High aromatase expression in uterine leiomyoma tissues of african-american women. J. Clin. Endocrinol. Metab. 2009, 94, 1752-1756. [CrossRef] [PubMed]

114. Kashani, B.N.; Centini, G.; Morelli, S.S.; Weiss, G.; Petraglia, F. Role of medical management for uterine leiomyomas. Best Pract. Res. Clin. Obstet. Gynaecol. 2016, 34, 85-103. [CrossRef] [PubMed]

115. Kaunitz, A.M. Aromatase inhibitor therapy for uterine bleeding in a postmenopausal woman with leiomyomata. Menopause 2007, 14, 941-943. [CrossRef] [PubMed]

116. Hilario, S.G.; Bozzini, N.; Borsari, R.; Baracat, E.C. Action of aromatase inhibitor for treatment of uterine leiomyoma in perimenopausal patients. Fertil. Steril. 2009, 91, 240-243. [CrossRef] [PubMed]

117. Varelas, F.K.; Papanicolaou, A.N.; Vavatsi-Christaki, N.; Makedos, G.A.; Vlassis, G.D. The effect of anastrazole on symptomatic uterine leiomyomata. Obstet. Gynecol. 2007, 110, 643-649. [CrossRef] [PubMed]

118. Shozu, M.; Murakami, K.; Segawa, T.; Kasai, T.; Inoue, M. Successful treatment of a symptomatic uterine leiomyoma in a perimenopausal woman with a nonsteroidal aromatase inhibitor. Fertil. Steril. 2003, 79, 628-631. [CrossRef]

119. Doherty, L.; Mutlu, L.; Sinclair, D.; Taylor, H. Uterine fibroids: Clinical manifestations and contemporary management. Reprod. Sci. 2014, 21, 1067-1092. [CrossRef] [PubMed]

120. Song, H.; Lu, D.; Navaratnam, K.; Shi, G. Aromatase inhibitors for uterine fibroids. Cochrane Database Syst. Rev. 2013, CD009505. [CrossRef] [PubMed]

121. Duhan, N.; Madaan, S.; Sen, J. Role of the aromatase inhibitor letrozole in the management of uterine leiomyomas in premenopausal women. Eur. J. Obstet. Gynecol. Reprod. Biol. 2013, 171, 329-332. [CrossRef] [PubMed]

122. Sayyah-Melli, M.; Mobasseri, M.; Gharabaghi, P.M.; Ouladsahebmadarek, E.; Rahmani, V. Comparing the effect of aromatase inhibitor (letrozole) + cabergoline (dostinex) and letrozole alone on uterine myoma regression, a randomized clinical trial. Eur. J. Obstet. Gynecol. Reprod. Biol. 2017, 210, 257-264. [CrossRef] [PubMed]

123. Leone Roberti Maggiore, U.; Scala, C.; Venturini, P.L.; Ferrero, S. Preoperative treatment with letrozole in patients undergoing laparoscopic myomectomy of large uterine myomas: A prospective non-randomized study. Eur. J. Obstet. Gynecol. Reprod. Biol. 2014, 181, 157-162. [CrossRef] [PubMed]

124. Bizzarri, N.; Ghirardi, V.; Remorgida, V.; Venturini, P.L.; Ferrero, S. Three-month treatment with triptorelin, letrozole and ulipristal acetate before hysteroscopic resection of uterine myomas: Prospective comparative pilot study. Eur. J. Obstet. Gynecol. Reprod. Biol. 2015, 192, 22-26. [CrossRef] [PubMed]

125. Rains, C.P.; Bryson, H.M.; Fitton, A. Cabergoline. A review of its pharmacological properties and therapeutic potential in the treatment of hyperprolactinaemia and inhibition of lactation. Drugs 1995, 49, 255-279. [CrossRef] [PubMed] 
126. Sankaran, S.; Manyonda, I.T. Medical management of fibroids. Best Pract. Res. Clin. Obstet. Gynaecol. 2008, 22, 655-676. [CrossRef] [PubMed]

127. Melli, M.S.; Farzadi, L.; Madarek, E.O. Comparison of the effect of gonadotropin-releasing hormone analog (diphereline) and cabergoline (dostinex) treatment on uterine myoma regression. Saudi Med. J. 2007, $3,445-450$.

128. Vahdat, M.; Kashanian, M.; Ghaziani, N.; Sheikhansari, N. Evaluation of the effects of cabergoline (dostinex) on women with symptomatic myomatous uterus: A randomized trial. Eur. J. Obstet. Gynecol. Reprod. Biol. 2016, 206, 74-78. [CrossRef] [PubMed]

129. ESHRE Capri Workshop Group. Noncontraceptive health benefits of combined oral contraception. Hum. Reprod. Update 2005, 11, 513-525. [CrossRef]

130. Munro, M.G.; Critchley, H.O.; Fraser, I.S.; FIGO Menstrual Disorders Working Group. The figo classification of causes of abnormal uterine bleeding in the reproductive years. Fertil. Steril. 2011, 95, 2204-2208. [CrossRef] [PubMed]

131. Qin, J.; Yang, T.; Kong, F.; Zhou, Q. Oral contraceptive use and uterine leiomyoma risk: A meta-analysis based on cohort and case-control studies. Arch. Gynecol. Obstet. 2013, 288, 139-148. [CrossRef] [PubMed]

132. Fraser, I.S.; Romer, T.; Parke, S.; Zeun, S.; Mellinger, U.; Machlitt, A.; Jensen, J.T. Effective treatment of heavy and/or prolonged menstrual bleeding with an oral contraceptive containing estradiol valerate and dienogest: A randomized, double-blind phase III trial. Hum. Reprod. 2011, 26, 2698-2708. [CrossRef] [PubMed]

133. Bromham, D.R.; Booker, M.W.; Rose, G.L.; Wardle, P.G.; Newton, J.R. A multicentre comparative study of gestrinone and danazol in the treatment of endometriosis. J. Obstet. Gynaecol. 1995, 15, 188-194. [CrossRef]

134. Selak, V.; Farquhar, C.; Prentice, A.; Singla, A. Danazol for pelvic pain associated with endometriosis. Cochrane Database Syst. Rev. 2007, CD000068. [CrossRef]

135. Coutinho, E.M. Gestrinone in the treatment of myomas. Acta Obstet. Gynecol. Scand. Suppl. 1989, 150, 39-46. [CrossRef] [PubMed]

136. Coutinho, E.M. Treatment of large fibroids with high doses of gestrinone. Gynecol. Obstet. Investig. 1990, 30, 44-47. [CrossRef]

137. Coutinho, E.M.; Goncalves, M.T. Long-term treatment of leiomyomas with gestrinone. Fertil. Steril. 1989, 51, 939-946. [CrossRef]

138. Aggarwal, B.B.; Kumar, A.; Bharti, A.C. Anticancer potential of curcumin: Preclinical and clinical studies. Anticancer Res. 2003, 23, 363-398. [PubMed]

139. Feng, T.; Wei, Y.; Lee, R.J.; Zhao, L. Liposomal curcumin and its application in cancer. Int. J. Nanomed. 2017, 12, 6027-6044. [CrossRef] [PubMed]

140. Shishodia, S.; Amin, H.M.; Lai, R.; Aggarwal, B.B. Curcumin (diferuloylmethane) inhibits constitutive NF- $\mathrm{kB}$ activation, induces G1/S arrest, suppresses proliferation, and induces apoptosis in mantle cell lymphoma. Biochem. Pharmacol. 2005, 70, 700-713. [CrossRef] [PubMed]

141. Malik, M.; Mendoza, M.; Payson, M.; Catherino, W.H. Curcumin, a nutritional supplement with antineoplastic activity, enhances leiomyoma cell apoptosis and decreases fibronectin expression. Fertil. Steril. 2009, 91, 2177-2184. [CrossRef] [PubMed]

142. Tsuiji, K.; Takeda, T.; Li, B.; Wakabayashi, A.; Kondo, A.; Kimura, T.; Yaegashi, N. Inhibitory effect of curcumin on uterine leiomyoma cell proliferation. Gynecol. Endocrinol. 2011, 27, 512-517. [CrossRef] [PubMed]

143. Grygielko, E.T.; Martin, W.M.; Tweed, C.; Thornton, P.; Harling, J.; Brooks, D.P.; Laping, N.J. Inhibition of gene markers of fibrosis with a novel inhibitor of transforming growth factor- $\beta$ type I receptor kinase in puromycin-induced nephritis. J. Pharmacol. Exp. Ther. 2005, 313, 943-951. [CrossRef] [PubMed]

144. Laping, N.J.; Everitt, J.I.; Frazier, K.S.; Burgert, M.; Portis, M.J.; Cadacio, C.; Gold, L.I.; Walker, C.L. Tumor-specific efficacy of transforming growth factor- $\beta$ RI inhibition in Eker rats. Clin. Cancer Res. 2007, 13, 3087-3099. [CrossRef] [PubMed]

145. Chwalisz, K.; Taylor, H. Current and emerging medical treatments for uterine fibroids. Semin. Reprod. Med. 2017, 35, 510-522. [CrossRef] [PubMed]

146. Gao, M.; Guo, K.M.; Wei, Y.M.; Ma, M.M.; Cai, J.R.; Xia, T.T.; Ye, Q.J. Aspirin inhibits the proliferation of human uterine leiomyoma cells by downregulation of k-Ras-p110 $\alpha$ interaction. Oncol. Rep. 2017, 38, 2507-2517. [CrossRef] [PubMed] 
147. Lee, B.S.; Margolin, S.B.; Nowak, R.A. Pirfenidone: A novel pharmacological agent that inhibits leiomyoma cell proliferation and collagen production. J. Clin. Endocrinol. Metab. 1998, 83, 219-223. [CrossRef] [PubMed]

148. Hayton, C.; Chaudhuri, N. Managing idiopathic pulmonary fibrosis: Which drug for which patient? Drugs Aging 2017. [CrossRef] [PubMed]

149. Hassan, M.H.; Fouad, H.; Bahashwan, S.; Al-Hendy, A. Towards non-surgical therapy for uterine fibroids: Catechol-O-methyl transferase inhibitor shrinks uterine fibroid lesions in the Eker rat model. Hum. Reprod. 2011, 26, 3008-3018. [CrossRef] [PubMed]

150. Young, M.V.; Schwartz, G.G.; Wang, L.; Jamieson, D.P.; Whitlatch, L.W.; Flanagan, J.N.; Lokeshwar, B.L.; Holick, M.F.; Chen, T.C. The prostate 25-hydroxyvitamin D-1 $\alpha$-hydroxylase is not influenced by parathyroid hormone and calcium: Implications for prostate cancer chemoprevention by vitamin D. Carcinogenesis 2004, 25, 967-971. [CrossRef] [PubMed]

(C) 2017 by the authors. Licensee MDPI, Basel, Switzerland. This article is an open access article distributed under the terms and conditions of the Creative Commons Attribution (CC BY) license (http://creativecommons.org/licenses/by/4.0/). 